\title{
THE IMPACT OF THE REGIONAL POLICY ON THE LOCAL ECONOMY - BULGARIAN CASE
}

DOI: http://dx.doi.org/10.18509/GBP.2019.57

UDC: 332.1(497.2)

\author{
Kliment Naydenov \\ Sofia University “St. Kliment Ohridski”, Faculty of Geology and Geography, \\ Department of Regional Development, Bulgaria
}

\begin{abstract}
The main objective of EU regional policy is to reduce disparities in terms of employment and income of the population, level of infrastructure development, economic development, etc. In 1957, when the six founding countries signed the Treaty of Rome, their aim was "to strengthen the unity of their economies and ensure their harmonious development by reducing the disparities existing between the various regions and the backwardness of the less favored regions." In practice, this is an economic development policy focused on problem areas. In practice, this is a policy based on solidarity. Solidarity is mentioned in the preamble to the Treaty on European Union, which states that community action is geared to economic and social cohesion, and especially to reducing disparities between the levels of development of individual regions. Economic and social cohesion is supported through regional, social and structural measures. The integrated approach dates from the time of the emergence of European cohesion policy. The Territorial Integrated Approach also highlights the need to work with a more flexible sense of geography. Geography continues to matter. The regional policy of the Republic of Bulgaria arises with the intention of defending the European model of social structure, in which the elements of free competition and social market economy are accompanied by goals related to the solidarity and promotion of specific priorities for economic, social and territorial development.
\end{abstract}

Keywords: economic development, territorial development, regional policy

\section{INTRODUCTION}

The main objective of EU regional policy is to reduce disparities in terms of employment and income of the population, level of infrastructure development and economic development. In 1957, when the six founding countries signed the Treaty of Rome, their aim was "to strengthen the unity of their economies and ensure their harmonious development by reducing the disparities existing between the various regions and the backwardness of the less favored regions." In practice, this is an economic development policy focused on problem areas. In practice, this is a policy based on solidarity. Solidarity is mentioned in the preamble to the Treaty on European Union, which states that community action is geared to economic and social cohesion, and especially to reducing disparities between the levels of development of individual regions. Economic and social cohesion is supported through regional, social and structural measures. The integrated approach dates from the time of the emergence of European cohesion policy. The Territorial Integrated Approach also highlights the need to work with a more flexible sense of geography. Geography continues to matter. The regional policy of the Republic of Bulgaria arises with the intention of defending the European model of social structure, 
in which the elements of free competition and social market economy are accompanied by goals related to the solidarity and promotion of specific priorities for economic, social and territorial development.

\section{MATERIALS AND METHODS}

Modern economic development is linked to trends such as globalization, regionalization and the knowledge-based economy. Of course, the first two trends are the opposite. The inexorable forces of globalization and regionalization have transformed the world's economic landscape in the late twentieth century and the beginning of the 21 st century. World trade and financial flows register unprecedented growth [3].

The main objective of EU regional policy is to reduce disparities in terms of employment and income of the population, level of infrastructure development, economic development, etc. In 1957, when the six founding countries signed the Treaty of Rome, their aim was "to strengthen the unity of their economies and ensure their harmonious development by reducing the disparities existing between the various regions and the backwardness of the less favored regions." This goal is inspired by the concern that some less developed regions will not be able to benefit from further market integration. In practice, this is an economic development policy focused on problem areas. In practice, this is a policy based on solidarity. Solidarity is mentioned in the preamble to the Treaty on European Union, which states that community action is geared to economic and social cohesion, and especially to reducing disparities between the levels of development of individual regions. Economic and social cohesion is supported through regional, social and structural measures. The integrated approach dates from the time of the emergence of European cohesion policy. The Territorial Integrated Approach also highlights the need to work with a more flexible sense of geography. Geography continues to matter. The regional policy of the Republic of Bulgaria arises with the intention of defending the European model of social structure, in which the elements of free competition and social market economy are accompanied by goals related to the solidarity and promotion of specific priorities for economic, social and territorial development.

The article uses the following methods: analysis and synthesis, comparison, induction and deduction.

\section{RESULTS AND DISCUSSION}

The main objective of EU regional policy is to reduce disparities in terms of employment and income of the population, level of infrastructure development, economic development, etc. In 1957, when the six founding countries signed the Treaty of Rome, their aim was "to strengthen the unity of their economies and ensure their harmonious development by reducing the disparities existing between the various regions and the backwardness of less favored regions". practice is an economic development policy focused on problem areas. By 2020 the EU aims to meet five concrete objectives - on employment, innovation, education, social inclusion, and climate/energy. Each Member State has adopted its own national targets in these areas [1].

The EU invests locally through its regional policy. It targets all regions and cities in the EU and contains measures to stimulate economic growth and employment and to improve the quality of life through strategic investment. Thanks to this active form of solidarity, citizens in less developed regions can take advantage of the opportunities offered by the world's largest market. In practice, this is a policy based on solidarity. Solidarity is 
mentioned in the preamble to the Treaty on European Union, which states that community action is geared to economic and social cohesion, and especially to reducing disparities between the levels of development of individual regions. Economic and social cohesion is supported through regional, social and structural measures. The integrated approach dates from the time of the emergence of European cohesion policy. Cohesion policy is the EU's main investment policy. It targets all regions and cities in the European Union in order to support job creation, enterprise competitiveness, economic growth, sustainable development and improve the quality of life of citizens. Cohesion Policy is a catalyst for further public and private funding, not only because it obliges Member States to cofinance from the national budget, but since it also creates investor confidence.

The EU Regional Policy is working on improvements in five key areas:

- investing in people by supporting access to employment opportunities, education and social inclusion

- supporting the development of small and medium-sized enterprises

- Strengthening research and innovation through investment and jobs in research

- improving the environment through large investment projects

- modernizing transport and energy production to tackle climate change, with a focus on renewable energy and innovative transport infrastructure.

The localization of a free zone is an essential element of the national strategy and an important approach in the development of regional policy for a given territory. This is one of the world-wide recognized forms of organizing production, especially of high-tech products, as well as creating conditions for providing modern technologies, as well as for moving foreign direct investments and accelerating the development of certain economic regions. Free economic zones are an important tool for regional development [2].

In order to reach these goals and address the diverse development needs in all EU regions, EUR 351.8 billion - almost a third of the total EU budget - has been set aside for Cohesion Policy for 2014-2020 [1].

Cohesion policy is vital to economic growth and social cohesion across Europe. For many cities, structural funds provide essential support for major investment programmes which directly impact on the quality of life of citizens and the liveability and attractiveness of cities.

Cohesion Policy is delivered through three main funds [1]:

- European Regional Development Fund (ERDF): aims to strengthen regional economic and social cohesion by investing in growth-enhancing sectors to improve competitiveness and create jobs. The ERDF also finances cross-border co- operation projects.

- European Social Fund (ESF): invests in people, with a focus on improving employment and education opportunities. It also aims to help disadvantaged people at risk of poverty or social exclusion.

- Cohesion Fund: invests in green growth and sustainable development, and improves connectivity in Member States with a GDP below 90\% of the EU-27 average.

After the events in 1989 Bulgaria underwent severe changes in terms of political, economic, institutional and fiscal system that led to inversion of the whole mechanism that powered the country [9]. The regional policy of the Republic of Bulgaria arises with the intention of defending the European model of social structure, in which the elements of free competition and social market economy are accompanied by goals related to the solidarity and promotion of specific priorities for economic, social and territorial development [8]. The territorial approach also highlights the need to work with a more 
flexible sense of geography, which may be on a small scale when it comes to islands or urban neighborhoods or on a large scale, as is the case with metropolitan regions or macro-regions such as the Baltic sea. Geography continues to matter. For example, some Cohesion Policy programs may aim to improve broadband access to parts of their region where the return on investment is not high enough to motivate companies to do so themselves. Other programs may wish to have a multi-regional dimension, allowing them to create a shared strategy for a functional area. Regional planning, on the other hand, offers solutions through a system of coordinated actions to solve the problems in the regions of the respective level. While regional policy focuses on intra-regional problemsolving mechanisms, regional planning focuses on a wider range of issues within the region, through the preparation and implementation of an integrated regional development strategy implemented by the relevant institutions (Territorial government bodies as well as local authorities). Spatial planning, understood in a wider context, looks at the way the site is organized and used, the available resources and the existing problems (natural, socio-economic, urban and infrastructural), the identified resources and problems being analyzed, evaluated and predicted, vision, alternatives (territorial models / spatial proposals) and a spatial strategy appropriate for implementation [5].

Adopting an integrated approach to regional economic development requires policy makers to use programming strategies that address real needs without succumbing to the temptation of relatively easy spending of resources for individual sectors. Local strategies should not be formulated in isolation, but strategies that have been applied in other areas, for example in neighboring regions, should be addressed. In this respect, European Cohesion Policy has experience in supporting the development of transregional coordination schemes, which are a necessary aid to EU regions in terms of mutual influence and the use of their synergies. In plain language, an integrated approach with coordinated action in policy areas can achieve better results than individual initiatives. Territorial planning in Bulgaria has developed dynamically over the last decades. From centrally planned secondary development in the years before 1989, it moved to new forms that put local communities at the center of decision-making. In the pre-1989 period, a determinant of spatial planning was the political one, decisions on the development of a territory are defined by the ruling political power that also has the power of power. In this way, lobbying is the basic principle and the allocation of funds is based on the principle of stronger influence of individual persons in the governing bodies. Assistance to individual regions is done through direct subsidy, but without any specific criteria and without effective control of the expenditure.

The Republic of Bulgaria is a centralized unitary state divided into 28 districts and 265 municipalities. In addition, six planning regions are defined as a basis for planning, implementing and monitoring regional interventions on a decentralized basis and implementing partnerships consistent with EU regional policy practice. In their original form, planning regions (later designated as Level 2 areas)

Bulgaria sets the standards for the classification of NUTS territorial units as follows:

- 2 statistical units at NUTS 1 level

- 6 units at NUTS 2 level

- 28 NUTS 3 units

Following its official accession to the European Union (EU) on January 1, 2007, Bulgaria gained access to a significant amount of financial resources from the Structural and Cohesion Funds and the instruments in the field of agriculture and fisheries. The country had the opportunity to use these funds to overcome its significant backwardness in terms 
of overall economic development, state of infrastructure and living standards. EU assistance was particularly important in the period of economic crisis, reflecting very limited public and private investment, when EU funds were the main source of investment in the economy and job creation and preservation. The second programming period for the country (2014-2020) received access to ESIF funds amounting to 9.9 billion euros (The analysis does not include the funds that the country will receive under the first pillar of the EU Common Agricultural Policy, as well as the funds for implementing crossborder programs, and the Operational Program "Foods" is not included in the Impact Assessment for the 2014-2020 programming period), intended to co-finance 10 programs. Compared to the period 2007-2013, the available resource is higher by $5.2 \%$.

The impact of Cohesion Policy on Bulgarian society and local economy is good and the effects of investments build up over the long term. The results are already visible. More than 12000 projects have been supported over the last 10 years and the achievements made in the country through implementation of the European funds are crucial: more than 800000 students participated in extracurricular and school activities; nearly 70000 unemployed were supported by taking specialised training; grants were provided in 1120 start-up enterprises; and more than 372000 new workplaces were established, etc.

Bulgaria is on 21st place in the European Union in Gross Domestic Product (GDP) in 2016. The country is in a currency board regime that binds the national currency to the euro. Bulgaria has an open market economy, a medium-sized private sector and a relatively small domestic market. After Bulgaria's accession to the EU, there is a steady process of community equity alignment, which has been significantly slowed down in the years of the global economic crisis but has accelerated again in the last three years. In 2016, the country's economy grew by $3.9 \%$, ranked fourth in this indicator among all EU Member States. The main driver of economic growth is exports that exceeded their precrisis levels as early as 2011. In 2016, its share in GDP was 64\%. The real growth in commodity exports from $7.9 \%$ in 2016 is the third highest in the EU, and this is realized under conditions of unstable external environment. In 2016-2017, the country's economy accelerated its growth to nearly $4 \%$ per year, with all areas, without exception, increasing welfare and living standards as measured by GDP per capita, wages and household incomes. While in the previous years of economic recovery after the recession of 2009 the positive processes covered only a few of the areas, in the last two years the economic revival has spread across the whole country [7].

There is a grave disparity in social and economic development between the center and the periphery both within the country and at regional and local levels [10]. The North-western region is the most scarcely populated, which is mostly affected by outgoing migration ows, with the poorest economic development, high unemployment and serious social problems. The Southwestern region is the most densely populated region due to better living and employment opportunities, offered by the capital city. Similar disparities exist at the district and municipal levels. However, some areas are characterized by clearly overtaking growth rates for all these indicators, due to a booming local economy and catching-up wage and income growth. Such a regional economic tiger in the last edition is Plovdiv District, which in 2016 marks 10\% growth of GDP per capita and 9\% wage growth. Considering that in 2017 the incomes in the area grew by $16 \%$, most probably 2017 was very strong for the local economy. Other areas with a relatively high GDP growth per capita in 2016 are the strong economic centers of Bourgas and Stara Zagora, as well as the smaller but fast-growing economies of Pernik, Lovech, Targovishte, Razgrad and Gabrovo. Growth in income and consumption has led to improvements in 
almost all areas of the main indicator of absolute poverty, the share of people living in material deprivation. Good economic growth went hand in hand with a strong labor market in most areas. Moreover, 2017 saw record employment rates among the most active population, at 15-64, in most areas. Employment is now about $70 \%$ of the population aged 15-64 on average for the country, with all areas in the strongest economic centers - the districts of Sofia, Plovdiv and Stara Zagora already exceed $70 \%$. Unemployment in most areas is already approaching record-low levels since 2008, but there are still areas where the ratio remains two-digit, which points to serious structural problems in local labor markets, low population mobility or even statistical weaknesses in regional data. Almost all areas with unemployment over 10\% (population 15-64) are clustered in North Bulgaria - Vidin, Vratsa, Pleven, Silistra, Targovishte, Shumen. Exceptions in southern Bulgaria are the regions of Sliven and Smolyan. The ability of regions to attract local and foreign investment is a key factor in their good economic development. For a consecutive year, the regions with a growth in direct foreign investment per capita in 2016 are among the strongest economic centers - Sofia and the large Sofia region, Plovdiv, Burgas, Gabrovo, Rousse, as well as the less developed Targovishte, where investment leads to a rapid increase in employment [6]. Unfortunately, the processes of infrastructure and especially road infrastructure are not so positive. Despite the continuing construction of new sections of the existing highways, the share of motorways and first-class roads remains real unchanged overall for the country. At the same time, the proportion of roads with good pavement quality decreases in 2017 and is already below $40 \%$ of all, indicating the lagging rehabilitation of existing roads [6].

\section{CONCLUSION}

The group of "informal" regions are formed by joining districts and/or municipalities, related to the specific zoning of the country or for specialised studies or programmes. First in this group are the "targeted support areas", which pursuant to the RD Act can be differentiated in the territory of NUTS 3 regions and cover one or more neighbouring municipalities. They form the territorial base for the concentration of resources for narrowing intra-regional disparities. Second in the informal regions group are the areas for cross-border cooperation. The priority areas are the Danube river and the Black Sea area, which are connected to the EU regional strategy for the Danube river and the Integrated Maritime Policy. This group includes also the Euroregions, established for the preservation of common cultural values and supporting social and economic cohesion. These regions have no direct political power, but have shared history, common interests and goals, developed strategic and multi-level partnerships [4].

Low corporate tax rates and personal income taxes improve the business environment and encourage investment. After joining the EU, Bulgaria improves collection and the tax culture of society is rising. Good business conditions are confirmed by international charts. According to the World Bank Doing Business Report 2017, Bulgaria ranks 39th among 190 countries in terms of business regulation efficiency and 20th among EU member states.

The four freedoms in the EU - free movement of persons, goods, services and capital have given us excellent opportunities and expanded our horizons considerably. We have a wider choice of products and services, more opportunities to work, live and study abroad, a huge potential market and it is easier to do business and to cooperate with different EU countries and regions. At the same time, we face a major challenge related 
to the 'brain drain'. The emigration of young, highly skilled and well-educated people is an issue for Bulgaria, as well as for the rest of the Eastern and Central European countries. The advantages in the field of regional policy and local economy, after the EU accession, are associated with the enhanced role of the regions, the introduction of new principles of planning and programming of regional development, and the integration of the sectoral policy priorities, which binds them to the national territory. With the introduction of a series of important, hierarchically related statutory strategic documents, some order and rhythm was established in regional and spatial planning, however a lot of work still needs to be done for institutional and expert capacity development [4].

\section{REFERENCES}

[1] An introduction to EU Cohesion Policy, 2014--2020, European Commission, 2014

[2] Naydenov Kl., Ivanov M., THE ROLE OF FREE ECONOMIC ZONES FOR THE DEVELOPMENT OF THE REGIONAL ECONOMY, 5th SGEM International Multidisciplinary Scientific Conferences on SOCIAL SCIENCES and ARTS SGEM2018, Urban Planning, Architecture and Design Issue 5.2, 2018, стр.553-561, ISSN (print):2367-5659, ISBN:978-6197408-60-7, doi:10.5593/sgemsocial2018/5.2

[3] Naydenov Kl., M. Ivanov - Анализ и оценка на инвестиционната привлекателност и конкурентоспособност на регионите (Analysis and assessment of the investment attractiveness and competitiveness of the regions), РЕГИОНАЛНА ИКОНОМИКА И УСТОЙЧИВО РАЗВИТИЕ, Сборник с доклади от научна конференция Том 1, Издателство „Наука и икономика” Икономически университет - Варна, ISBN 978-954-21-0956-3, стр. 143, p.143

[4] Regionalisation in Bulgaria: reducing regional disparities, 2018, AER

[5] Попов А., Ст. Димитров, Кл. Найденов, Б. Борисова, М. Каразлатева, М. Николов, А. Димитрова, МЕТОДИЧЕСКИ УКАЗАНИЯ ЗА ИЗГОТВЯНЕ НА РЕГИОНАЛНИТЕ СХЕМИ ЗА ПРОСТРАНСТВЕНО РАЗВИТИЕ, Министерство на регионалното развитие и благоустройство, София, 2016; Popov A., Dimitrov, Kl. Naydenov, B. Borissova, M. Karazlateva, M. Nikolov, A. Dimitrova, METHODOLOGICAL GUIDELINES FOR THE PREPARATION OF REGIONAL SPACE DEVELOPMENT SCHEMES, Ministry of Regional Development and Public Works, Sofia, 2016

[6] Регионални профили - показатели за развитие, 2018, Институт за пазарна икономика, стр. 5; Regional Profiles - Indicators for Development, 2018, Institute for Market Economics, p. 5

[7] Иванов М., Найденов Кл., Особености на регионалното икономическо развитие в БъЛГария, РЕГИОНАЛНА ИКОНОМИКА И УСТОЙЧИВО РАЗВИТИЕ - 2017, 2018, стр.65-78

[8] Найденов Кл., Иванов М., Регионални особености при трансфера на инструменти, влияещи при определянето на националната и регионалната политика на страната, Международният трансфер на административни модели и инструменти: възможности, ограничения и рискове, издателство:УИ-"Св.-Климент-Охридски", 2017, стр.183-195, ISBN:9789540744063

[9] Dimitrov St., E. Todorova, THE SPATIAL "RESPONSE" OF THE TRANSITION: THE CASE OF BULGARIA, INTERNATIONAL SCIENTIFIC CONFERENCE GEOBALCANICA 2015 5-7 JUNE 2015 SKOPJE, REPUBLIC OF MACEDONIA, 2015, стр.451-456, doi:http://dx.doi.org/10.18509/GBP.2015.57

[10] Радева К., Водни ресурси и обществена сигурност, Юбилеен сборник посветен на проф. д-р Петър Славейков, издателство: Мелани, 2018, стр.131-135 